Historic, Archive Document

Do not assume content reflects current scientific knowledge, policies, or practices. 



\section{Price List, 1922}

\section{THE TEXAS NURSERY COMPANY}

\section{SHERMAN, TEXAS}

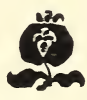

When buying nursery stock, give a thought to these two points - that nearly all trees of a given kind and age look so much alike that even an expert cannot definitely determine their quality by their outward appearance,- - that you cannot judge nursery stock econ omy by the price, because the real cost of a tree or plant is based on the pleasure it affords or the prof $t$ it produces. Then send us your orders as our long string of Blue Ribbons awarded us by competent judges is ewidence of our stock possessing the qualities you should get in trees and plants.

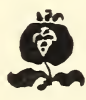

With each order we furnish free, a copy of "How to Plant and care for Tree and Plants." 
The following prices will apply to all stock listed in our catalogue. Subject to change WITHOUT NOTICE.

\section{FRUIT DEPARTMENT}

PEACHES.

APPLES,

\begin{tabular}{|c|c|c|c|}
\hline & Eac & Dozen & 100 \\
\hline Extra large & 100 & $\$ 10 \quad 00$ & $\$ 8000$ \\
\hline Large & 75 & ถัก & 6000 \\
\hline 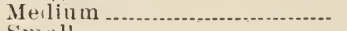 & 50 & 500 & 40 00 \\
\hline 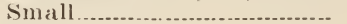 & 35 & 350 & 2800 \\
\hline
\end{tabular}

APRICOTS.

COMPASS CHERRY.

PLUMS.

PEARS.

CHERRIES.

Extra large

125

Large

10()

Medium...

small..

1250

1000

750

$50 \quad 50$

10000

800()

6() 0 ()

$\pm 000$

\section{QUINCES.}

Extra large

150

Large

140

Medium 1 25

simall.

1500

$1 \pm 00$

12 ริ)

100()

12000

112 un

10000

8000

JAPAN PERSIMUONS.

Medium

1500

small

150

125

1250

12000

$1(1000$

POMEgRANATE.

Melium

100

1000

8000

CITRUS FRUITS.

3 to + feet.

300

3000

$2+000$

250

1 to 2 feet

25110

17.50

20000

FIGS.

Larue ......

100

$10(00)$

$1 \pm 0 \quad 00$

Medium

75

Smal

ริ)

8000

750

6000

+0 00

MULBERRIES, Everbearing.

6 to 8 feet.

5 to 6 feet

100

75

$+t 0$ i feet. 50

1000

8000

6000

$+000$

\section{NUT TREES}

PECANS. Grafted or budiled. Each

i) to 6 feet

350

$+t_{0} 5$ feet

300

3 to + feet

200

2 to 3 teet

150

18 to 24 inch........................

12 to 18 inch

100

750

\section{ALHONDS.}

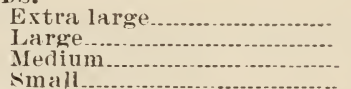

125

I) $) \mathrm{z}$.

100

350

$300(0)$

2ख) 00

20100

150

$2+000$

$161)(0)$

1250

1:2) $0(1)$

11000

$100 \mathrm{rr}$

SO 00

100

$12 \div 0$

10000

10 (10

8()$(0)$

7.5

7 :

G() $(10$

$5(1)$

5110

$400(1)$

SPECIALLY SELECTED SOECIMEYS AT RBOPOZJIOYATE RLICE 
CHESTNUTS. Spanish.

2 to 3 feet

Each

Dozen

$100:-$

FILBERTS,

3 to 4 feet.......................... $150 \quad 1500$

WALNUT, BLACK.

\begin{tabular}{|c|c|c|c|}
\hline 5 to 7 feet. & 125 & 1250 & 100.00 \\
\hline 4 to 5 feet... & 100 & 1000 & 8000 \\
\hline 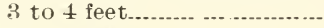 & 75 & 750 & 6000 \\
\hline & & & \\
\hline 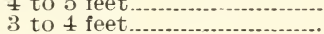 & 150 & $\begin{array}{ll}20 & 00 \\
15 & 00\end{array}$ & $\begin{array}{l}160 \\
120\end{array}$ \\
\hline - & 100 & 1000 & 80 \\
\hline
\end{tabular}

\section{SMALL FRUITS AND GARDEN ROOTS}

GRAPES.

Special varieties 2 yr....

Special varieties 1 y r....

standard varietles 2 y

Standard $v$ arieties 1 y $\mathrm{r}$

GOOSEBERRIES.

$75 \quad 750$

50,00

$50 \quad 500$

4000

50

35

50

500

4000

CURRAYTS.

50

350

500

3800

HIMALAYA BERRY,

50

LOGANBERRY.

75

500

500

750

\section{GARDEN ROOTS}

Asparagus, 2 vear old

Asparagus, 2 year old.........

Garlen sage.

Horse Radish

Rhubarb.

\begin{tabular}{rrr} 
& 100 & 500 \\
-25 & 250 & 2000 \\
$\cdots 25$ & 100 & 500 \\
\hdashline & 250 & 2000 \\
\hline
\end{tabular}

BLACKBERRIES

25

Dallas.

150

Early Harvest.

McDonald.

200

Robison

150

Haupt...

200

Hopkins

250

Queen

100

1000

DEW BERRIES.

Au^tin Dewberry.

150

400

600

400

600

750

650

850

2500

3500

2500

3500

5000

3500

6000

Rogers Dewberry

400

600

$-2500$

3500

STRA WBERRIES.

Standar.

Everbearing

150

200

400

600

2000

3000

RASPBERRIES,

Price except St. Regis....... 300

850

1500

7500

10000

\section{SHADE TREES}

SHADE TREES. Standard

4 to 5 inch caliber.

Each

$31 / 2$ to 4 inch caliber

1000

3 to $31 / 2$ inch caliber

80()

600

$21 / 2$ to 3 inch caliber

400

2 to $21 / 2$ inch caliber

250

$11 / 2$ to 2 iuch caliber

200

8 to 10 feet

150

6 to 8 feet,

100

$\mathrm{Doz}$
10000

100

8000

6000

4000

2500

2000

1500

1000

4 to 6 feet,

50

500

$800 \quad 00$

64000

48000

32000

20000

16000

12000

8000

4000

SPECIALLY SELECTED SPECIUENS AT PROPORTIQXATE PRICES 
CYPRESS, Deciduous.

$\begin{array}{lll}\text { Each } & \text { Doz } & 100 \\ 500 & 5000 & 40000 \\ 350 & 3.500 & 28000 \\ 250 & 2500 & 20000\end{array}$

$11 / 2$ to 2 inch caliber

6 to 7 feet

2500

20000

6 feet

25) 00

16009

5 feet

2000

12000

EMPRESS TREE.

6 to 8 feet

5 to 6 feet.

2500

20000

4 to 5 feet

2000

16000

3 to 4 feet

250

200

1500

12000

$1000 \quad 8000$

JA PAN VARNISH.

2 to $21 / 2$ inch caliber

6 to 8 feet.

3500

28000

2500

20000

12000

8000

4 to 5 feet

3 to 4 feet

1000

750

6000

MULBERRY, PAPER WHITE. Non-Fruiting.

2 to $21 / 2$ Inch ealiber.

$3500 \quad 28000$

$11 / 2$ to 2 inch caliber

350

6 to 7 feet

5 to 6 feet

250

$20(1)$

4 to 5 feet

OAKS. Except Live Oaks.

\begin{tabular}{|c|c|c|}
\hline & 1500 & \\
\hline inch.. & 1250 & \\
\hline inch & 1000 & \\
\hline $21 / 2$ inch & 750 & \\
\hline $2 \mathrm{lnch}$ & 600 & \\
\hline 0 to 12 feet. & $\therefore 50$ & 3500 \\
\hline to 10 feet............ & 300 & 3000 \\
\hline 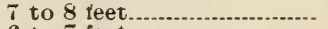 & 250 & \\
\hline to 7 feet... & 200 & \\
\hline to 6 feet. & 150 & 1500 \\
\hline to 5 feet. & 125 & 1250 \\
\hline to 4 feet,....................... & 100 & 1000 \\
\hline
\end{tabular}

TEXAS UMBRELLA.

2 to $21 / 2$ inch callber

$11 / 2$ to 2 inch callber

$\begin{array}{rrrr}3 & 50 & 35 & 00 \\ 2 & 00 & 20 & 00 \\ 1 & 25 & 12 & 50 \\ 75 & 7 & 50 \\ & 50 & 5 & 00 \\ & & & \\ 2 & 50 & 25 & 00 \\ 1 & 25 & 1250 \\ 1 & 00 & 10 & 00 \\ & 75 & 7 & 50\end{array}$

5 to 6 feet

4 to 5 feet

3 to 4 feet

WREPING WILLOW.

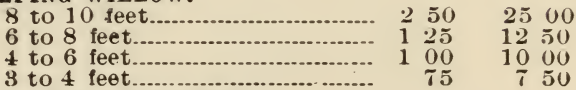

SHADE TREE SEEDLIYGS.

Rlack Locust, Bols d'Arc, Catalpa Speclosa, and Russian Mulberry.

In 1000 lots

In 5000 to 10,000 lots.

$\$ 2500$ per .11

28000

$16(100$

10000

6000

4000

\begin{tabular}{|c|c|c|c|}
\hline WEKL & & Doz. & \\
\hline 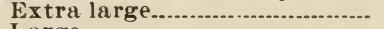 & 150 & 1500 & 120 \\
\hline Large......................... & 100 & & \\
\hline 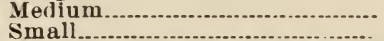 & 75 & $\begin{array}{ll}750 \\
5 & 00\end{array}$ & $\begin{array}{l}00 \\
40\end{array}$ \\
\hline
\end{tabular}


ALTHEA. Named varieties.

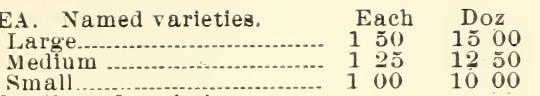

LILACS Named varietles.

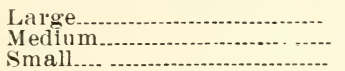

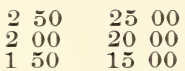

VINES. Except as noted

(lematis, large white

.50

'lematis, purple.

100

5 00

1000

$100 \quad 1000$

('lematis, rerl.

100

1000

('lematis, star of India...........

Bittersweet.

100

1000

$\begin{array}{lll}75 & 750 \\ 75 & 750\end{array}$

Iry, Boston

Ivy, English

1000

Pipe Vine.

Queen's Wreath.

100

100

1000

\section{HEDGE PLANTS}

Barberry Japanese, 12 to 18 inch

Doz.

Box, Dwarf, 6 to 8 inch

$$
4 \text { to } 6 \text { inch }
$$

75

4000

Box, Tree, 12 to 18 inch. light

8 to 12 inch, light

Evergreen Euonymus, is to 24 inch,light

12 to 18 inch, light
8 to 12 inch, light.-
6 to 8 inch, light....

350

450

300

750

500

750

5 00

300

200

100

2800

3600

2400

6000

4000

6000

4000

2400

1600

Hardy Orange. Hedge sizes.

2 to 3 feet

18 to 24 inch.



2000

12 to 18 inch

6 to 12 inch

200

1600

150

100

1200

800

Privet, Amoor River. 3 to 4 feet, light....

2 to 3 feet. light....................

18 to 24 inch, light.

500

300

250

12 to 18 inch, light

Privet, California. 3 to 4 feet 2 to 3 fi et.

18 to 24 inch.

12 to 18 inch.

3000

2400

2000

1600

200

$\begin{array}{llll}3 & 00 & 2 \pm & 00 \\ 2 & 00 & .16 & 00\end{array}$

$\begin{array}{llll}2 & 00 & 1600 \\ 1 & 25 & 10 & 00\end{array}$

100

800

CLIPPED SPECIMENS.

Box in tubs..............\$35 00 per pair

Without tubs......25 00 per pair

Amour Privet .......... 300 each, 500 per palr

Bay Trees.......................................

CONIFEROUS EVERGREENS.

Each

Doz.

100

IRBOR VIT E, Chinese

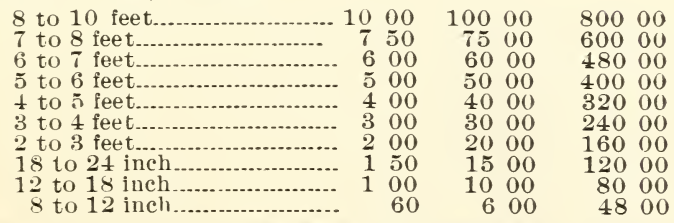


ARBOR VIT.E, Compacia, Chinese Gollen, Pyramidal.

\begin{tabular}{|c|c|c|c|}
\hline & Each & Duz. & $\frac{100}{600}$ \\
\hline to 5 feet. & 150 & 1500 & $\begin{array}{l}600 \\
+00\end{array}$ \\
\hline feet. & 50() & & $\begin{array}{l} \pm 00 \\
\pm \leqslant 0\end{array}$ \\
\hline 2 to 3 feet & 350 & 3500 & $2 \leq 0$ \\
\hline 18 to 24 inch. & 250 & 2500 & 200 \\
\hline to is inch. & 200 & 20100 & 160 \\
\hline to 1 & 150 & 1500 & 100 \\
\hline
\end{tabular}

ARBOR VITA, Dwarf, (Biota Aurea Nana)

18 to $2+$ inch. +130 to 0()

12 to 18 inch..................... $250 \quad 2500$

8 to 12 inch .................. $125 \quad 1250$

CEDAR. Red.

8 to 10 feet

7 to 8 feet

800

(j) 00

(j t t) 7 feet

万) $\mathrm{O}()$

i) to 6 feet

$+00$

+ to 5 leet

300

3 to + feet

200

2 to 3 feet

$1 \div 0$

18 to 24 inch

125

12 to $18 \mathrm{inch}$

100

CRDRUA ATLANTICA.

8 to 10 feet.......................... 2000

7 to 8 feet...................................... 1250

6 to 7 feet...... 10 ou

5 to 6 feet........................... 750

4 to 5 fept ........................ 6 ()(

CEDRUS DEUDARA.

12 to 15 feet

$50(0)$

10 $\mathrm{to} 1: 2$ feet

3500

4 to 5 feet.

600

3 to $t$ feet

$50(0$

2 to 5 feet

350

8000

6000

$6+000$

5000

4000

उ० 00

2000

1.500

1250

$10 \mathrm{vu}$

+80 Uu

to0 $0(1)$

320 (1)

$2+110(1)$

1 (i) ) 0

120 (O)

10000

8000

JUNIPER, IRISH.

4 to 5 feet............................

$3 t_{1} 4$ feet................................. 30

20000

12500

10 () 00

7500

6000

50000

35000

6() 0 (

5000

3500

2 to 3 feet

250

18 to $2+$ inch .............................

12 to 18 inch.................... 150

PINE, AUSTRIAN AND STOTI H.

4 to 5 feet ................... 5000

3 to 4 feet ........................ 350 35 00

2 to 3 feet.

18 to 24 inch.................... $20\left(\begin{array}{lll}20 & 00\end{array}\right.$

$12 \mathrm{to} 1 \mathrm{~s}$ inch...................... 1 50 1500

BROAD.LEAVED EVERGREENS.

A KBLTĹ (Abelia) Flowing Shrub.

( 0 fert

2 to 3 feet

130

1 ()(

1.2 ti, 1 is inct

$\div 5$

150()

$100(1)$

RBERRY, Holly-Leaved.

3 to + feet

$200 \quad 2000$

2 to 3 feret

150

15100

1. to $24 \mathrm{inch}$

$100 \quad 1000$

12 to 18 inch

$75 \div 50$

BOX, TREE.

$2+$ to 30 inch

$30(1$

3000

18 to $2+$ iuch

$200 \quad 2000$

12 to 18 inch

10100

8 to 12 inch

100

7 50 
CAPE JASMINE.

3 to + feet

Each Doz.

2 to 3 feet.

$\begin{array}{rrr}250 & 2500 \\ 150 & 1500 \\ 100 & 1000 \\ 60 & 600\end{array}$

18 to 24 inch

60

600

EVERGREEN EUONYMUS.

3 to 4 feet

$\begin{array}{llll}2 & 50 & 2500 \\ 150 & 1500\end{array}$

2 to 3 feet

18 to 24 inch

10()

11) 00

HOLLY, American

+ to 5 feet.

500

5000

3 to 4 feet

350

3500

2 to 3 feet

250

2500

18 to 24 inch

175

1750

12 to 18 inch

125

1250

JAPAN PRIVET. Bushy.

3 to 4 feet

$1 \frac{00}{15}$

1000

750

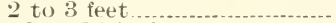

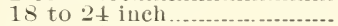

12 to 18 inch

35

500

3.50

standard or tree form $50 \mathrm{c}$ per foot of height.

8000

6000

4000

2800

JASMINE. Italian Yellow.
3 to 4 feet
$125 \quad 1250$
2 to 3 feet
18 to 24 inch.
100
10()()
75
750

MAGNOLIt, Grandiflora.

12 to 15 feet......................... 500

10 to 12 feet ....................... 50 00

8 to 10 feet ................................. 3500

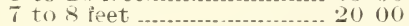

35000

20 () 00

fito $T$ f

510650

10000

7500

5000

4 to 5 fert $\ldots \ldots \ldots \ldots \ldots$

3 to 4 feet...................... 50

2 to 3 feet ...................... 50

3500

2500

18 to $2+$ inch.................. $500 \quad 2000$

12 to 18 inch .................. $150 \quad 1500$

MAHONIA. Aquafolia.

2 to 3 feet

18 to 24 ine :

OAK, LIVE.

12 t 18 inch

$\begin{array}{llll}300 & 30 & 00 \\ 200 & 20 & 00 \\ 150 & 15 & 00 \\ 500 & 50 & 00 \\ 500 & 50 & 35 & 00 \\ 3 & 50 & 25 & 00 \\ 2 & 50 & & 20 \\ 2 & 00 & 50 & 00 \\ 500 & 50 & 00 \\ 300 & 30 & 00 \\ 300 & 00 & 20 & 00 \\ 2 & 50 & 15 & 00\end{array}$

6 to 7 feet

i) to 6 feet

+ to 5 feet

PH( T) T

TINTA. 3 to 4 fret ........

2 to 3 feet

18 to 24 inch

12 to 18 inch

150

1.) 00

W'I, PEAch, Prices same as for H ignolia dirandiflora.

GRASSES.

B\&tra large
Large
Merdium



BULBS AYB PEREXYILČ.

Amaryllis, Belladonna.....

Amaryliis, Equestris.........

Amaryllis, Vi itata...........

Blazing sitar

Boltonia, white....................

Boltonia. lilac

(2)

50()

$\bar{s}()$

ก()

500

35

500

3.5

350

35

350

350

Bouncing Bet

25

250

4000

$+000$

4000

2800

2800

28 (0)

2000 
Chrysanthemum, hardy....

Canna, Austria.

\begin{tabular}{|c|}
\hline $\begin{array}{l}\text { Alionse Bouvier } \\
\text { Buttercup. } \\
\text { Egandale } \\
\text { Hungaria } \\
\text { J. D. Fisle.... } \\
\text { Koros. } \\
\text { Louisiana } \\
\text { King Humert }\end{array}$ \\
\hline
\end{tabular}

Chinese Bell Flower, blue..-

Crinum, Augustrum.........

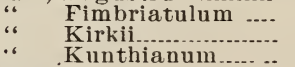

Daffodils

Dahlias

Day Lily, orange..............

Eupatorium vellww and lemon

False Dragon Head.........

Gaillardia

Gas Plant, white

(n)

Gladiolus, Mixed colors...

"“ Named varieties

Golden Glow

Goldenrod.

Hollyhock

H vacinth, Dutch

Iris, German

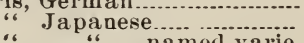

“ Sn " named varie.

Larkspur

Lavender Cotton................

Lespedeza..............................

Narcissus.

Orange Sunflower.............

Pentstemon........................

Peony, ansorted colors.....

" Named varieties, $75 \mathrm{c}$ to

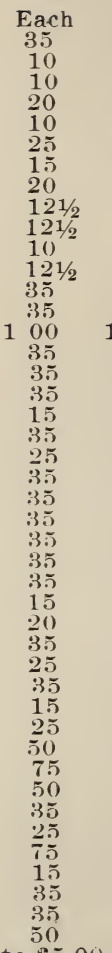

Doz.

350

100

2800

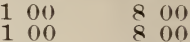

200

16. 00

100

250

150

800

2000

1200

200

1600

1000

1000

800

1000

2800

2800

8000

2800

2800

2800

1200

2800

2000

2800

2800

2800

2800

2800

.2800

1200

1600

2800

2000

2800

1200

20) 00

3500

5000

3.500

2800

20 00

6० 00

1200

2800

28 ก

4000

Perennial Pea

$\$ 5.00$ ench

2000

2800

Perennial Phlox................

Plumbago, Larpentre.......

Red Hot Poker................

Sea Lavender.

$25 \quad 250$

उร 3 กัด

$50 \quad 50(0)$

$35 \quad 350$

$35 \quad 3.50$

Shasta Dais.

35

Stoke's Aster..................... 35

Stonecrop

3.50

$35 \quad 351$

Tickseed ..............................

Tuberose, Mexican

$25 \quad 250$

Tulips, Assorted

$\begin{array}{lll}15 & 1 & 50 \\ 35 & 3 & 50\end{array}$

Uprlght Virgin Bower.......

Violets, single plants.

100

10

25

$25(1)$

4000

$\simeq 800$

2.800

2800

28110

28 (o)

$20(00$

756

1000

$2 \times 00$

(i) $(0)$

2000

BOSES. Extra strong...................

No. 1

$100 \quad 1000$

so 00

6o) 00

$75 \quad 750$

50

Spl varieties, Marechiel Nell

50

1250

40 an

10000 